\title{
Analyses of the effects of potato cyst nematodes (Globodera pallida) on growth, physiology and yield of potato cultivars in field plots at three levels of soil compaction
}

\author{
By M VAN OIJEN ${ }^{1,2}$, F J DE RUIJTER ${ }^{2}$ and R J F VAN HAREN ${ }^{3}$ \\ ${ }^{1}$ Wageningen Agricultural University, Department of Theoretical Production \\ Ecology, $P$ O Box 430, 6700 AK Wageningen, The Netherlands \\ ${ }^{2}$ Research Institute for Agrobiology and Soil Fertility (AB-DLO), $P O$ Box 14, \\ 6700 AA Wageningen, The Netherlands \\ ${ }^{3}$ Research Institute for Plant Protection (IPO-DLO), P O Box 9060, $6700 \mathrm{GW}$ \\ Wageningen, The Netherlands
}

(Accepted 11 December 1995)

\begin{abstract}
Summary
Field experiments were carried out in 1991 and 1992 on sandy soil highly infested with the potato cyst nematode Globodera pallida. Half the trial area was fumigated with nematicide to establish two levels of nematode density. Three levels of soil compaction were made by different combinations of artificial compaction and rotary cultivation. Two potato cultivars were used in 1991 and four in 1992.

Both high nematode density and soil compaction caused severe yield losses, of all cultivars except cv. Elles which was tolerant of nematode attack. The effects of the two stress factors were generally additive. Analysis of the yield loss showed that nematodes mainly reduced cumulative interception of light while compaction mainly reduced the efficiency with which intercepted light was used to produce biomass. This indicates that nematodes and compaction affect growth via different damage mechanisms.

Nematodes reduced light interception by accelerating leaf senescence, by decreasing the specific leaf area and indirectly by reducing overall crop growth rate. Partitioning of biomass between leaves, stems and tubers was not affected by nematode infestation but compaction decreased partitioning to leaves early in the growing season while increasing it during later growth stages.

The effects of nematodes and compaction on root length dynamics and nutrient uptake were also additive. This suggests that the commonly observed variation in yield loss caused by nematodes on different soil types is not related to differences in root system expansion between soils of various strength.

Cv. Elles, which showed tolerance of nematodes by relatively low yield losses in both experiments, was characterised by high root length density and thick roots. These characteristics did not confer tolerance of soil compaction, since compaction affected root lengths and tuber yields equally in all cultivars.

In the first experiment only, high nematode density led to decreased root lengths and lower plant nutrient concentrations. The yield loss which occurred in the second experiment was attributed to the effects of nematodes on other aspects of plant physiology.
\end{abstract}

Key words: Light interception, light use efficiency, photosynthesis, biomass partitioning, leaf senescence, root senescence, nutrient uptake 


\section{Introduction}

Cyst nematodes (Globodera spp.) may cause severe yield losses in potato. The amount of loss depends on the potato cultivar, the genotype and density of the nematode, and the soil type (Trudgill, 1986; Evans \& Haydock, 1990). How these factors affect yield loss is not completely clear. The ranking of potato genotypes for tolerance of cyst nematodes varies between years and sites (Dale et al., 1988; Hancock \& Holliday, 1992). Whitehead \& Nichols (1992) showed that soil density may be involved in the site effect. They found that the mean yield loss of two cultivars in two years increased from $40 \%$ to $56 \%$ when compacted soil, severely infested with Globodera rostochiensis Woll., was loosened. Soil compaction strongly retards the extension of potato root systems (Boone, Bouma \& De Smet, 1978), and may indirectly arrest nematode population development. To clarify such interactions, closer examination of the mechanisms by which nematodes cause yield loss seems warranted.

Yield loss is often associated with reduced light interception by the crop due to reduced crop leaf area (Trudgill, Marshall \& Phillips, 1990; Haverkort, Boerma, Velema \& Van de Waart, 1992). Whether infection by nematodes reduces leaf area by decreasing leaf growth, accelerating leaf senescence, lowering the specific leaf area, or by a combination of these mechanisms, is unclear.

Yield loss may further be associated with effects of the nematodes on photosynthesis. Thirty days after planting four potato cultivars in pots of soil with $100 \mathrm{eggs}^{-1}$ of $G$. pallida Stone, photosynthetic rates per unit leaf area were $70 \%$ lower than in uninfested controls (Schans \& Arntzen, 1991). The photosynthetic rates increased again in the following weeks. Since this research was carried out under artificial conditions, with little rooting space in the pots, limited nutrient availability, and very high nematode densities, it is still unclear whether nematodes also impair photosynthesis under field conditions, and to what degree the effect may account for observed yield losses.

Two hypotheses have been put forward for the physiological mechanisms underlying the nematode effect. Trudgill (1980), Trudgill, Evans \& Parrott (1975) and Trudgill \& Cotes $(1983 a, b)$ proposed that nematodes reduce size and efficiency of the root system, leading to chronic nutrient deficiency and early crop senescence. Schans (1991) and Schans \& Arntzen (1991), on the other hand, asserted that cyst nematodes primarily affect the hormonal balance of the plant, leading to stomatal closure and impaired crop photosynthesis. According to the latter hypothesis, disturbance of carbon metabolism, and not nutrient metabolism, impairs crop growth. Evidence from field experiments is scarce. Schans' (1991) hypothesis has so far not been tested in the field, while Trudgill (1980) found stronger reductions of plant nutrient concentrations by nematodes in pot experiments than in the field.

The objective of the research presented in this paper was to identify the major ways in which potato cyst nematodes affect crop growth in the field. The effects of nematodes on leaf growth, senescence and photosynthesis of field-grown nematode-tolerant and intolerant potato cultivars were assessed. The effects were measured at various levels of soil compaction, to examine how soil type affects the magnitude of yield loss. We also studied the effects of treatments on root system size and activity and crop nutrient status to examine possible mechanisms of damage and to explain the variation between cultivars and soils in yield loss caused by cyst nematodes.

\section{Materials and Methods}

\section{Experimental factors}


sandy soil (4.8-6.2\% organic matter; $\mathrm{pH} 4.9)$ infested with Globodera pallida, near Assen, the Netherlands. Three experimental factors were included: nematode density, level of soil compaction, and cultivar.

In both experiments half the area was fumigated about six weeks before planting with sodium methyldithiocarbamate (Monam $510 \mathrm{~g} \mathrm{litre}^{-1}$ a.i.; 400 and 600 litre ha $^{-1}$ in 1991 and 1992, respectively) to establish a lower level of nematode population density. Two to four weeks after fumigation, initial nematode density was estimated by soil sampling. In each plot (1991: $\mathrm{n}=48 ; 1992: \mathrm{n}=96$ ), about five $\mathrm{dm}^{3}$ soil was taken, cysts were filtered out and put in potato root diffusate to count the number of emerging second stage juveniles (Van Haren, 1995).

Three levels of soil compaction were established, one week before planting in both experiments, by driving three (severely compacted), one (lightly compacted) or zero (noncompacted) times over the soil with a $1 \mathrm{~m}$ wide motorised roller of $2700 \mathrm{~kg}$. The density of the non-compacted soil was decreased further by means of rotary cultivation.

The effects of compaction treatments on soil strength were measured in all plots once during each growing season by means of penetrometry (Bengough, 1991). In 1991, the effects of compaction on soil pore size distribution and total pore volume between depths of 0.02 and $0.27 \mathrm{~m}$ were assessed in each plot by measuring water loss from intact wet soil samples subjected to a range of suction tensions (Glinski \& Lipiec, 1990).

In 1991, two late maturing, G. pallida-resistant potato cultivars were used, Darwina and Elles; in 1992 the early maturing, susceptible cvs Bintje and Mentor were added (Anon., 1992). Farming practice suggests that only $\mathrm{cv}$. Elles has a high tolerance of nematodes (M Boerma, H L B Assen, personal communication, 1990). In April of both years, seed tubers of these cultivars were planted in containers under an open-air rain shelter (1991) or in a greenhouse (1992). Four weeks after planting the tubers were taken out of the soil, and ongrowing shoots with roots were carefully detached. These single-stem plantlets, with an average length of $15 \mathrm{~cm}$, were transplanted to the trial fields, on 16 May 1991 and 13 May 1992. The plantlets were set out at a spacing of $0.25 \mathrm{~m} \times 0.25 \mathrm{~m}$, on flat soil, no ridges were made, to promote homogeneous rooting. Plot size was $4.5 \mathrm{~m} \times 3.0 \mathrm{~m}$, giving a total of 216 plants per plot.

In both years fertiliser was applied on the basis of soil samples taken to $0.4 \mathrm{~m}$ deep, to give pre-planting levels of $\mathrm{N}, \mathrm{P}$ and $\mathrm{K}$ of $0.023,0.030$ and $0.050 \mathrm{~kg} \mathrm{~m}^{-2}$, respectively. The fungicide maneb/fentin acetate was sprayed several times, according to normal farming practice, for protection against Phytophthora infestans. In 1991 natural rainfall was sufficient to keep the crops amply provided with water, but in 1992 a total of $150 \mathrm{~kg}$ water m${ }^{-2}$ was supplied between planting and the end of June.

In both years a split-plot design was used with four randomised blocks. Each block contained six main plots, for the six combinations of fumigation and soil compaction treatments. The subplots within the main plots were randomly allocated to the two (1991) or four (1992) cultivars used.

\section{Measurements}

Ground cover by green foliage was measured weekly. In 1991 a metal frame $0.75 \mathrm{~m} \times 0.75 \mathrm{~m}$, divided in 100 equal squares, was used to estimate percentage ground cover visually as the number of squares more than half filled with green leaves (Haverkort, Uenk, Veroude \& Van de Waart, 1991). In 1992 ground cover was assessed using portable equipment for measuring red and green reflectance of the crop. The two methods give comparable data (Haverkort et al., 1991).

Shoot and tuber biomass were measured at four harvest dates (1991: 10 June, 2 and 24 
July, 19 August; 1992: 15 June, 6 July, 3 and 24 August). At each harvest, patches of nine neighbouring plants per plot were harvested for separate determination of dry mass of tubers, stems, green, yellow and dead leaves. At least $0.5 \mathrm{~m}$ (i.e. two border plants) separated patches harvested at different dates. The area of a sample of green leaves was measured for calculation of the leaf area index. Fresh and dry weight, nitrogen, phosphorus and potassium content of leaves, stems and tubers and, in 1991 only, nitrate content of the leaves were also determined at each harvest. The nutrient concentrations were determined in only two of the four blocks. After foliage death, tuber yield was assessed in a final harvest of 24 plants per plot, taken from the central plot area. In 1992, measurements on plants growing on lightly compacted soil were restricted to ground cover and final tuber yield.

Diurnal courses of crop photosynthetic rate of cv. Darwina, in non- and severely compacted soil at both levels of nematode density, were measured at ambient light intensity with mobile field equipment (Louwerse \& Eikhoudt, 1975). In 1991, photosynthesis was measured between 1 and 5 July, and between 29 July and 2 August. In 1992, measurements were carried out between 13 and 17 July, and between 10 and 14 August. Additional measurements of leaf photosynthetic rate at light saturation were taken concurrently in all cultivars. These measurements were done using a portable leaf chamber analyser (LCA; Analytical Development Co. (ADC), UK), while holding an incandescent lamp, providing $300 \mathrm{~W} \mathrm{~m}^{-2}$ of photosynthetically active radiation, over the enclosed leaf for at least one minute before taking readings.

Root weight and length were assessed at each harvest in 1991, and at the second and fourth harvests in 1992. In 1991, 36 soil core samples, each $200 \mathrm{~cm}^{3}$, were taken at nine positions in the plot, five directly below plants and four diagonally in between, at four depths $(0-0.1,0.1-0.2,0.2-0.3,0.3-0.4 \mathrm{~m})$. Pre-planting sampling in both trial fields had revealed poorly penetrable soil, with few nutrients and organic matter, below $0.4 \mathrm{~m}$ depth, so during the experiments sampling was largely restricted to the upper soil layers. For each depth the five samples taken below plants were mixed, as were the four samples taken between plants, and subsamples of $0.5 \mathrm{~kg}$ were derived. The same procedure was applied in 1992 except that only two depths were sampled (0-0.2 and $0.2-0.4 \mathrm{~m})$. The $0.5 \mathrm{~kg}$ subsamples were taken to the laboratory, roots were washed free from soil by hydropneumatic elutriation (Smucker, McBurney \& Srivastava, 1982) and root length was determined by the line intersect counting method (Tennant, 1975). After counting, the roots were collected to determine their fresh and dry weight. Total root length $\left(\mathrm{km} \mathrm{m}^{-2}\right)$ was calculated as the average root length density $\left(\mathrm{m} \mathrm{m}^{-3}\right)$ for the various sampling positions, multiplied by $0.4 \times 10^{-3}$ to account for the $0.4 \mathrm{~m}$ rooting depth, and for conversion from $\mathrm{m}$ to $\mathrm{km}$.

Root length was also assessed non-destructively in the field, by the use of mini-rhizotrons placed in all plots, except those with the intermediate level of soil compaction. The minirhizotrons were glass tubes $1.20 \mathrm{~m} \times 0.06 \mathrm{~m}$ placed vertically in the soil to a depth of $0.85 \mathrm{~m}$, exactly in between plants, so their outer circumference was $0.15 \mathrm{~m}$ away from the four nearest planting positions. Twice each year (16 and 30 July 1991; 14 July and 12 August 1992) video recordings were made of the rooting profile along the tubes (Upchurch \& Ritchie, 1983). The tapes were later examined to estimate the rate of root senescence, by counting the fraction of roots present at the first recording that had disappeared or visibly deteriorated by the time of the second recording.

Air temperature and incident solar radiation data throughout the growing season were obtained from Eelde weather station about $17 \mathrm{~km}$ north of the trial fields. Soil temperature data for both years were taken from Nieuw-Beerta weather station $51 \mathrm{~km}$ east. These data compared well to soil temperatures measured at five positions in the trial fields from July to October 1992 , by thermocouples placed $0.10 \mathrm{~m}$ deep. Average soil temperatures were 
lower in 1991 than in 1992 from planting until the end of June $\left(13.7^{\circ} \mathrm{C}\right.$ compared to $\left.17.3^{\circ} \mathrm{C}\right)$, but were similar thereafter (about $18.7^{\circ} \mathrm{C}$ on average in July and August of both years).

\section{Calculations and statistical analysis}

The time courses of ground cover were used to calculate cumulatively intercepted photosynthetically active radiation (PARCUM: $\mathrm{MJ} \mathrm{m}^{-2}$ ) by the crops. Daily light inter-

- ception was estimated from ground cover percentage multiplied by the amount of incoming radiation. PARCUM was then calculated by summing all daily interception values over the growing season. The efficiency with which the crops used the intercepted light to produce biomass (LUE: $\mathrm{g} \mathrm{MJ}^{-1}$ ) was estimated by linear regression of total biomass at the various intermediate harvest dates on corresponding PARCUM-values (Monteith, 1977).

The rate of leaf senescence was quantified as the average percentage of leaves that died daily between the second and fourth harvest. This was calculated as minus the natural logarithm of the proportion of leaves that survived from harvest 2 till 4 , divided by the number of days between harvests.

Root senescence was quantified similarly as leaf senescence, using the video recordings from mini-rhizotrons of living and dead roots.

Statistical analysis was carried out separately for the 1991 and 1992 experiments. All measurements were analysed using analysis of variance (ANOVA) corresponding to the split-plot designs used. Standard errors of difference between treatments at given degrees of freedom were derived from the ANOVAs.

\section{Results}

\section{Nematicide and compaction treatments}

Cyst nematode populations in non-fumigated soil were $12 \pm 2.0(\mathrm{SEM} ; \mathrm{n}=24)$ and $22 \pm$ 2.6 (SEM; $\mathrm{n}=48$ ) living juveniles $\mathrm{cm}^{-3}$ soil in 1991 and 1992 , respectively. In fumigated soils there were $1 \pm 0.7(\mathrm{SEM} ; \mathrm{n}=24)$ and $3 \pm 0.5(\mathrm{SEM} ; \mathrm{n}=48)$ living juveniles $\mathrm{cm}^{-3}$ soil in 1991 and 1992, respectively.

In 1991 , soil bulk density between depths of 0.02 and $0.27 \mathrm{~m}$, was 1450,1390 and $1280 \mathrm{~kg}$ $\mathrm{m}^{-3}$, respectively, for severely, lightly and non-compacted soils, respectively. In 1992, soil densities were 1460,1390 and $1300 \mathrm{~kg} \mathrm{~m}^{-3}$, respectively.

The effect of the treatments on soil penetration resistance was most pronounced above a depth of $0.3 \mathrm{~m}$ (Fig. 1). Although the established ranges of soil bulk density were similar in the two years, soil rolling increased penetration resistance more in 1991 than in 1992 (Fig. 1). Moderate and severe compaction reduced total pore volume from $51 \%$ to $47 \%$ and $45 \%$, respectively. This reduction was mostly accounted for by a decreased frequency of pores wider than $0.0003 \mathrm{~m}$, in the soil layer above a depth of $0.10 \mathrm{~m}$. Since total pore volume was reduced only slightly, the compaction treatments will not have interfered with oxygen supply to the roots. Soil water content was also little affected by compaction. The water content between depths of 0.02 and $0.27 \mathrm{~m}$ in severely compacted, moderately compacted and loose soil was 270,270 and $250 \mathrm{~kg} \mathrm{~m}^{-3}$, respectively, on 27 June 1991, and 190,180 and $170 \mathrm{~kg} \mathrm{~m}^{-3}$ on 11 August 1992.

\section{Crop growth and yield}

High nematode density and soil compaction reduced crop growth rates more strongly in 1991 than in 1992 . Cultivars were equally affected by soil compaction but nematodes affected 


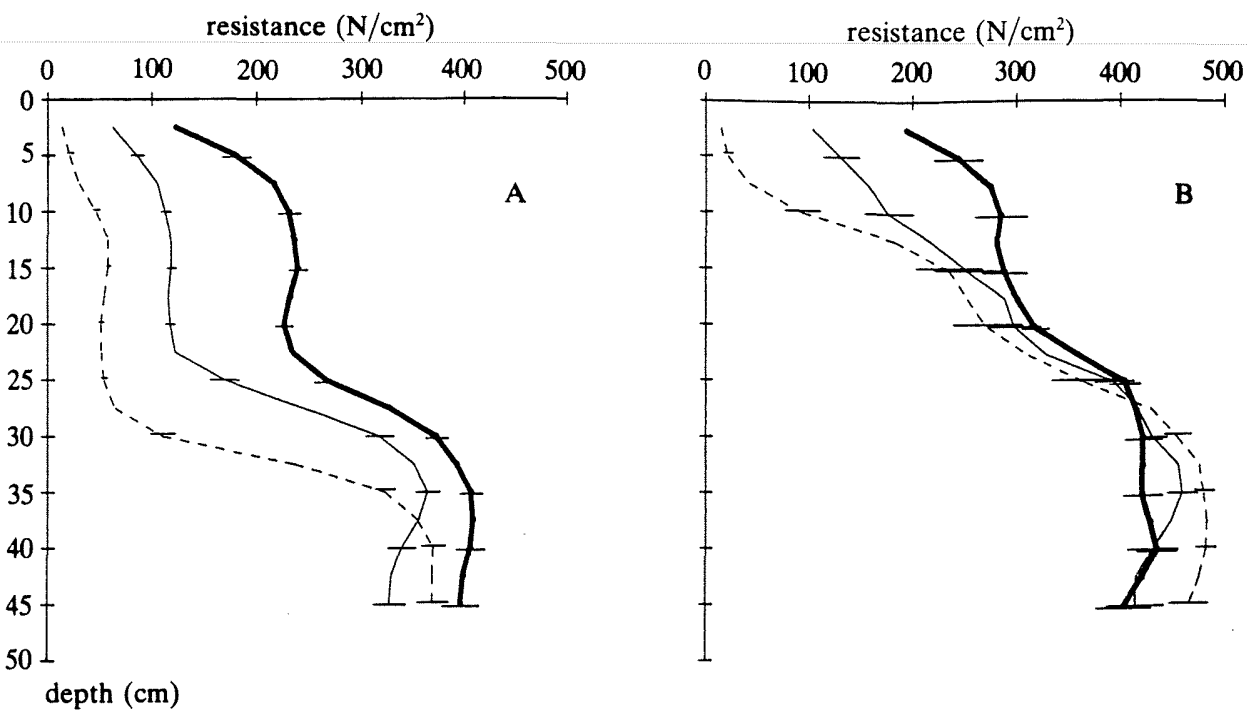

Fig. 1. Soil penetration resistance $\left(\mathrm{N} \mathrm{cm}^{-2}\right)$ between depths of 0 and $45 \mathrm{~cm}$, at three levels of soil compaction. Resistance was assessed by means of a $1 \mathrm{~cm}^{2}$ cone penetrometer. A: 3 October 1991 $(n=48)$; B: 8 August $1992(n=16)$. Horizontal bars indicate standard errors of means. - - - Noncompacted, - lightly compacted, $\longrightarrow$ severely compacted.

cv. Elles less than the other cultivars (Fig. 2). Combining nematodes and compaction reduced crop growth additively (not shown).

In both years, the reduced crop growth rates resulted in statistically significantly lower final tuber yields (Table 1). In 1991 the average yield loss was $40 \%$ with nematodes, and $37 \%$ with severe soil compaction. In 1992 the losses were only $12 \%$ and $16 \%$, respectively, for cvs Darwina and Elles, with similar values for cvs Bintje and Mentor (Table 1). The cultivars responded differently to the nematodes. Cv. Elles was not affected by high nematode density except in the compaction treatments of 1991 . The other cultivars always suffered yield loss by nematodes. No such differences between cultivars were found for the effect of soil compaction.

\section{Ground cover}

The variation in yield largely reflected the differences in time courses of ground cover. Fig. 3 shows this for the example of cv. Darwina in 1991. The other cultivars reacted similarly, apart from cv. Elles which suffered negligible effects from nematodes. Nematodes accelerated foliage death, especially in 1991, thus reducing ground cover mainly during the second half of the growing season. Compaction retarded or prevented canopy closure, but delayed crop senescence by one or two weeks.

\section{PARCUM and LUE}

The coefficients of determination $\left(\mathrm{r}^{2}\right)$ for regressions of biomass on cumulatively intercepted photosynthetically active radiation (PARCUM) averaged 0.96 and 0.93 for 1991 and 1992, respectively. High nematode density and soil compaction reduced both PARCUM and crop light use efficiency (LUE) in both years (Table 1). Nematodes reduced PARCUM of cvs Darwina and Elles on average by $41 \%$ in 1991 and by $10 \%$ in 1992 . The corresponding effects on LUE were $20 \%$ and $5 \%$ (Table 1). Severe compaction reduced LUE, by $30 \%$ and $11 \%$ in 1991 and 1992, respectively, whereas the corresponding reductions of PARCUM 
Darwina, 1991

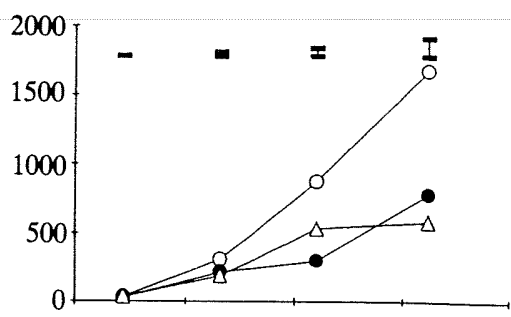

Elles, 1991

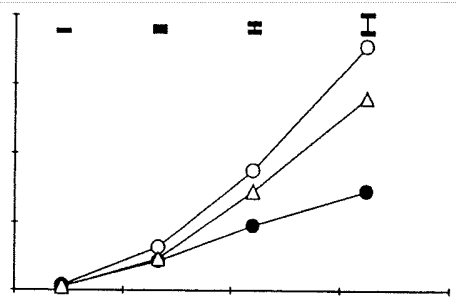

Darwina, 1992

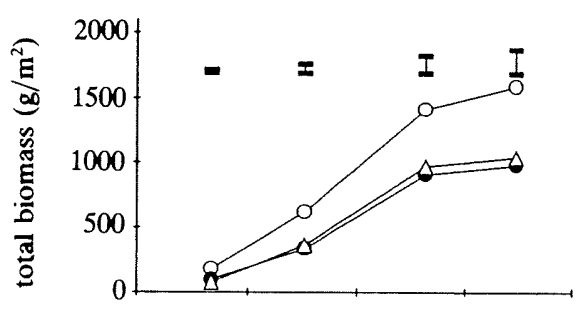

Bintje, 1992

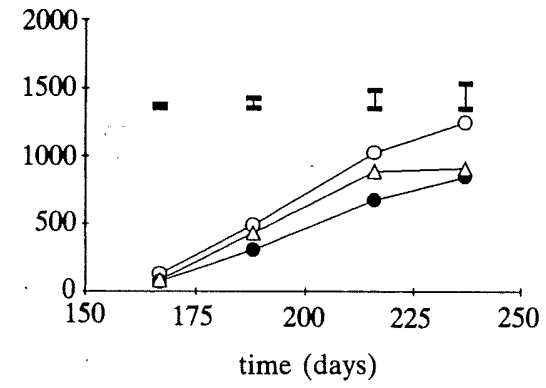

Elles, 1992

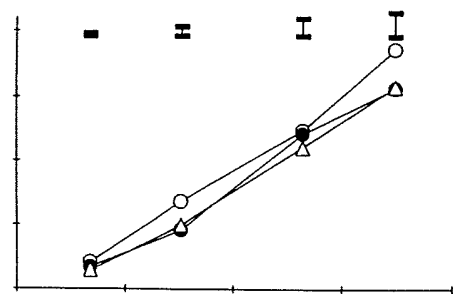

Mentor, 1992

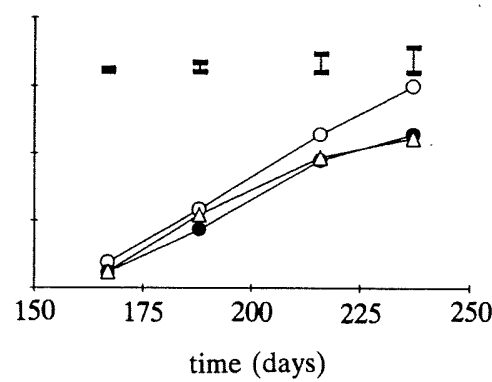

Fig. 2. Time courses of total dry biomass $\left(\mathrm{g} \mathrm{m}^{-2}\right)$, excluding roots, for various treatments. The final harvest date, when only tubers were weighed, is excluded. Vertical bars above harvest data indicate standard errors of difference $(1991: \mathrm{df}=18 ; 1992: \mathrm{df}=36)$. $O$ Non-compacted, fumigated; 0 compacted, fumigated; $\Delta$ non-compacted, not fumigated.

were $24 \%$ and $9 \%$. For LUE, no significant statistical interactions between cultivar and level of nematode density or compaction were found, but for PARCUM these interactions were significant in both years.

\section{Partitioning}

Data of dry weights for leaves, stems and tubers, as determined at the consecutive harvests, were used to calculate the changes during the growing season of partitioning of growth between plant organs (Fig. 4). In each case the fraction of growth occurring in tubers increased with time, but somewhat slower in cv. Elles than in the other cultivars. High 
Table 1. Final tuber yield ( $\mathrm{g}$ dry matter $\mathrm{m}^{-2}$ ), cumulative interception of photosynthetically active radiation (PARCUM: $M J \mathrm{~m}^{-2}$ ) and crop light use efficiency (LUE: $\left.g M^{-1}\right)$. SED = standard error of difference (value in parentheses is for the comparison within the same level of nematode density or compaction)

\begin{tabular}{|c|c|c|c|c|c|c|c|}
\hline & & & \multicolumn{2}{|c|}{ Nematode density } & \multicolumn{3}{|c|}{ Compaction level } \\
\hline & Year & Cultivar & Low & High & Loose & Light & Severe \\
\hline \multirow[t]{8}{*}{ Yield } & 1991 & Darwina & 1223 & 489 & 1013 & 863 & 692 \\
\hline & & Elles & 1363 & 1103 & 1475 & 1349 & 875 \\
\hline & & $\operatorname{SED}(\mathrm{df}=18)$ & \multicolumn{2}{|c|}{$55.9(37.3)$} & \multicolumn{3}{|c|}{$68.5(45.7)$} \\
\hline & 1992 & Darwina & 1177 & 890 & 1131 & 1032 & 938 \\
\hline & & Elles & 1386 & 1388 & 1510 & 1373 & 1279 \\
\hline & & Bintje & 757 & 612 & 906 & 654 & 492 \\
\hline & & Mentor & 1117 & 814 & 1012 & 937 & 948 \\
\hline & & $\operatorname{SED}(\mathrm{df}=54)$ & \multicolumn{2}{|c|}{$72.9(71.4)$} & \multicolumn{3}{|c|}{$89.3(87.4)$} \\
\hline \multirow[t]{8}{*}{ PARCUM } & 1991 & Darwina & 709 & 263 & 526 & 506 & 426 \\
\hline & & Elles & 777 & 625 & 791 & 737 & 576 \\
\hline & & $\operatorname{SED}(d f=18)$ & \multicolumn{2}{|c|}{$26.5(16.9)$} & \multicolumn{3}{|c|}{$32.4(20.7)$} \\
\hline & 1992 & Darwina & 772 & 649 & 726 & 720 & 684 \\
\hline & & Elles & 915 & 882 & 917 & 915 & 864 \\
\hline & & Bintje & 614 & 514 & 630 & 575 & 487 \\
\hline & & Mentor & 670 & 571 & 635 & 614 & 613 \\
\hline & & $\operatorname{SED}(\mathrm{df}=54)$ & \multicolumn{2}{|c|}{$18.4(18.1)$} & \multicolumn{3}{|c|}{$22.6(22.2)$} \\
\hline \multirow[t]{8}{*}{ LUE } & 1991 & Darwina & 2.31 & 1.76 & 2.32 & 2.06 & 1.72 \\
\hline & & Elles & 2.33 & 1.94 & 2.58 & 2.11 & 1.72 \\
\hline & & $\operatorname{SED}(\mathrm{df}=18)$ & \multicolumn{2}{|c|}{$0.108(0.106)$} & \multicolumn{3}{|c|}{$0.132(0.130)$} \\
\hline & 1992 & Darwina & 2.07 & 2.06 & 2.25 & - & 1.88 \\
\hline & & Elles & 2.16 & 1.95 & 2.09 & - & 2.02 \\
\hline & & Bintje & 1.82 & 1.69 & 1.85 & - & 1.66 \\
\hline & & Mentor & 2.03 & 1.82 & 2.04 & - & 1.81 \\
\hline & & $\operatorname{SED}(\mathrm{df}=36)$ & \multicolumn{2}{|c|}{$0.135(0.138)$} & \multicolumn{3}{|c|}{$0.135(0.138)$} \\
\hline
\end{tabular}

-, no data collected.

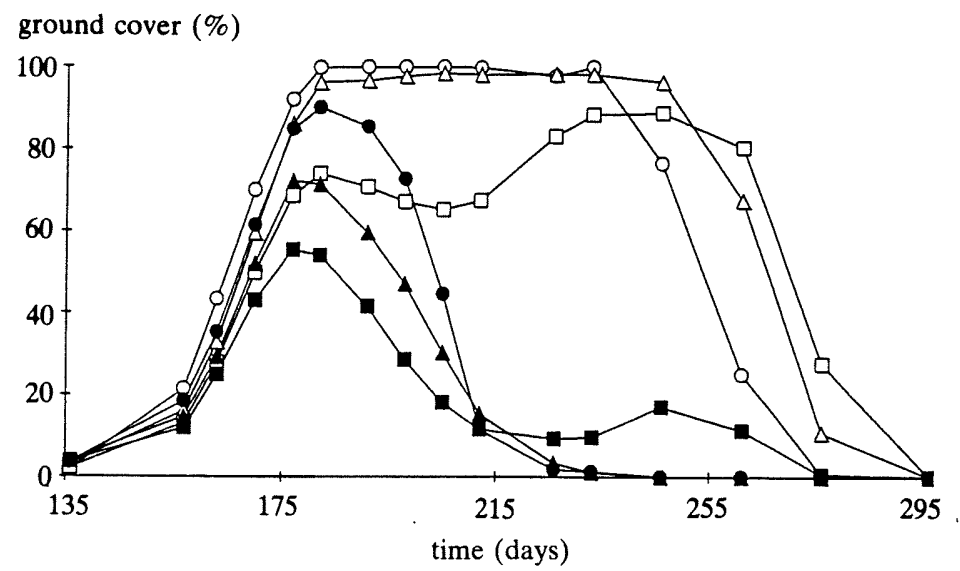

Fig. 3. Time courses of percentage ground covered by green leaf area for cv. Darwina, 1991. Fumigated: $-O-$ loose, $-\Delta-$ light comp., $-\square-$ sev. comp. Not fumigated: - - loose, $-\Delta-$ light comp., - - sev. comp. 
Darwina, 1991

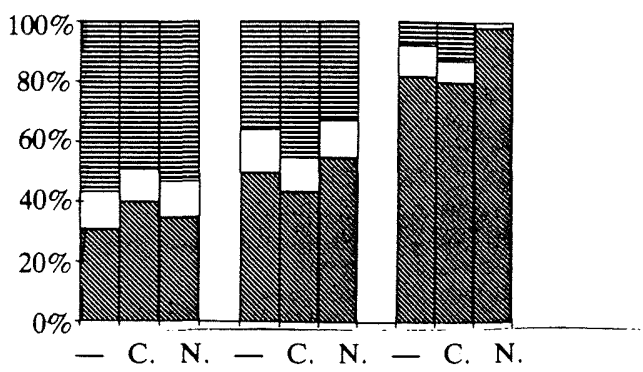

Darwina, 1992

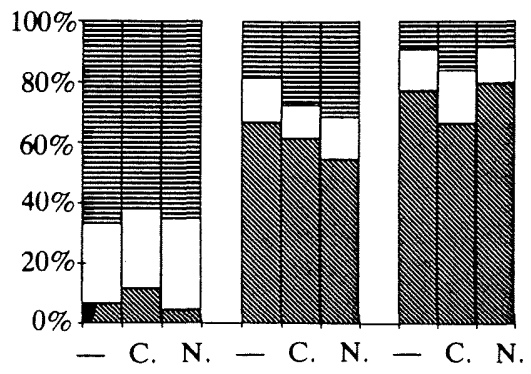

Bintje, 1992

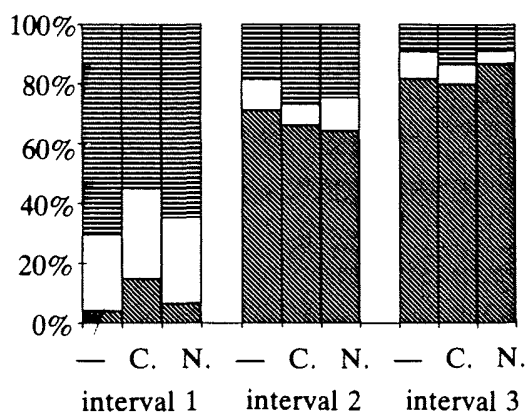

Elles, 1991

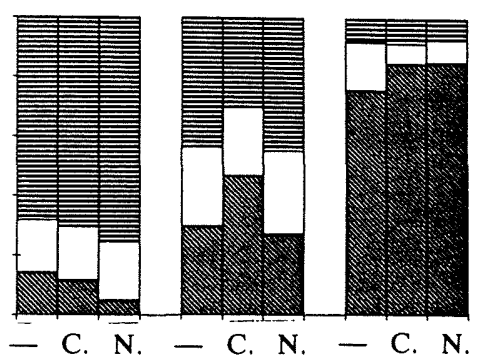

Elles, 1992

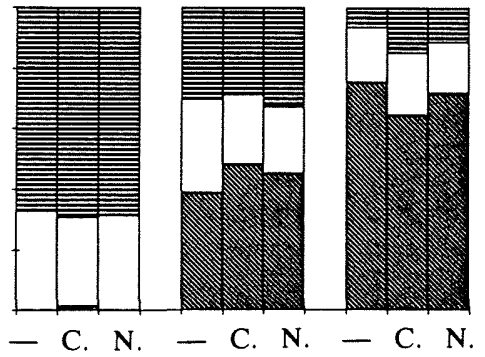

Mentor, 1992

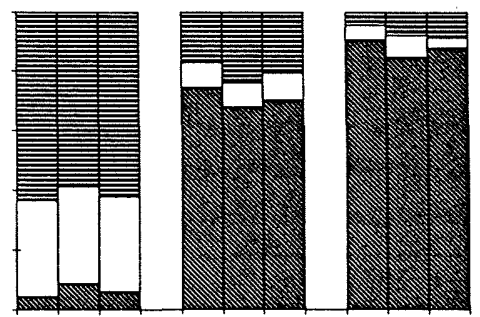

- C. N. - C. N. - C. N.

interval 1 interval 2 interval 3

Fig. 4. Partitioning of growth of dry biomass between leaves compacted, fumigated soil (-), severely compacted, fumigated soil (C) and non-compacted, not fumigated soil with high nematode density $(\mathrm{N})$. Partitioning was calculated for three consecutive time intervals: between planting and first harvest, between first and second harvest, and between second and fourth harvest. The three intervals are represented by the three groups of columns shown for each cultivar in both experimental years.

nematode density did not markedly affect partitioning in any of the cultivars. Compaction on the other hand, slightly decreased partitioning to leaves early in the growing season, but in most cases increased it thereafter. The partitioning patterns for the combination of severe soil compaction and high nematode density (not shown) were similar to those for soil compaction alone. Partitioning to stems was not affected by any of the treatments.

\section{Specific leaf area}

Specific leaf area (SLA) was determined at the first four harvest dates as the area-dry 
weight ratio of green leaves. In 1991 the average SLA was about $22 \mathrm{~m}^{2} \mathrm{~kg}^{-1}$ at all dates, but in 1992 SLA increased from $12.2 \mathrm{~m}^{2} \mathrm{~g}^{-1}$ at the first harvest to 18.6 and $17.5 \mathrm{~m}^{2} \mathrm{~kg}^{-1}$ at the third and fourth harvest, respectively.

In both years, SLA was reduced significantly and additively by nematodes and soil compaction. The effects were strongest in 1991, when severe compaction reduced SLA by $19 \%$ and nematodes reduced it by $9 \%$. In 1992 the effects were $7 \%$ and $4 \%$, respectively. SLA only differed significantly among cultivars in 1992, when SLA was about $16 \%$ higher in $\mathrm{cv}$. Elles than in the other cultivars.

\section{Leaf senescence}

The late maturing cv. Elles consistently showed the lowest rates of leaf senescence between the second and fourth harvests (Table 2). In 1991, both nematodes and soil compaction accelerated leaf senescence, but in 1992 nematodes had no effect, while compaction slightly delayed leaf senescence.

\section{Photosynthesis}

In each of the four periods that crop photosynthesis was measured, crop photosynthetic rate of $\mathrm{cv}$. Darwina varied strongly among treatments, as illustrated in Fig. 5A for the first five-day period. The variation was partly caused by differences in ground cover and, therefore, differences in light interception. To account for this, crop photosynthetic rate was analysed in relation to the amount of intercepted light, calculated as before (Fig. 5B). Photosynthetic Light Use Efficiency (PLUE) in non-light saturating conditions was determined as the initial slope of the linear regression discarding all data taken at ambient light intensities above $75 \mathrm{~W} \mathrm{~m}^{-2}$ photosynthetically active radiation (Table $3 ; \mathrm{r}^{2}$ averaged $0.91, \mathrm{n}>272$ ). PLUE was reduced by both nematodes and soil compaction. In both years, the effect of nematodes was strongest during the second period of measurement.

Measurements of leaf photosynthetic rate at light saturation (PMAX) showed similar effects as on PLUE (Table 3), apart from the measurements on 13 August 1992 where compaction increased PMAX.

Table 2. Average daily rate of leaf senescence between harvests 2 and $4\left(\%\right.$ day $\left.{ }^{-1}\right) . S E D=$ standard error of difference (value in parentheses is for the comparison within the same level of nematode density or compaction)

\begin{tabular}{|c|c|c|c|c|c|c|}
\hline \multirow[b]{2}{*}{ Year } & \multirow[b]{2}{*}{ Cultivar } & \multicolumn{2}{|c|}{ Nematode density } & \multicolumn{3}{|c|}{ Compaction level } \\
\hline & & Low & High & Loose & Light & Severe \\
\hline 1991 & $\begin{array}{l}\text { Darwina } \\
\text { Elles } \\
\text { SED }(d f=18)\end{array}$ & $\begin{array}{l}2.6 \\
0.7\end{array}$ & $\begin{array}{l}8.7 \\
1.0\end{array}$ & $\begin{array}{l}4.8 \\
0.5\end{array}$ & $\begin{array}{c}5.5 \\
0.8 \\
1.94(1.8\end{array}$ & $\begin{array}{l}6.5 \\
1.1\end{array}$ \\
\hline 1992 & $\begin{array}{l}\text { Darwina } \\
\text { Elles } \\
\text { Bintje } \\
\text { Mentor } \\
\text { SED }(d f=36)\end{array}$ & $\begin{array}{r}3.3 \\
2.0 \\
12.9 \\
8.3\end{array}$ & $\begin{array}{r}2.6 \\
2.5 \\
15.2 \\
11.2 \\
\end{array}$ & $\begin{array}{r}3.2 \\
2.6 \\
13.0 \\
13.4\end{array}$ & $\frac{-}{-}$ & $\begin{array}{r}2.7 \\
1.8 \\
15.1 \\
6.1\end{array}$ \\
\hline
\end{tabular}

- , no data collected. 

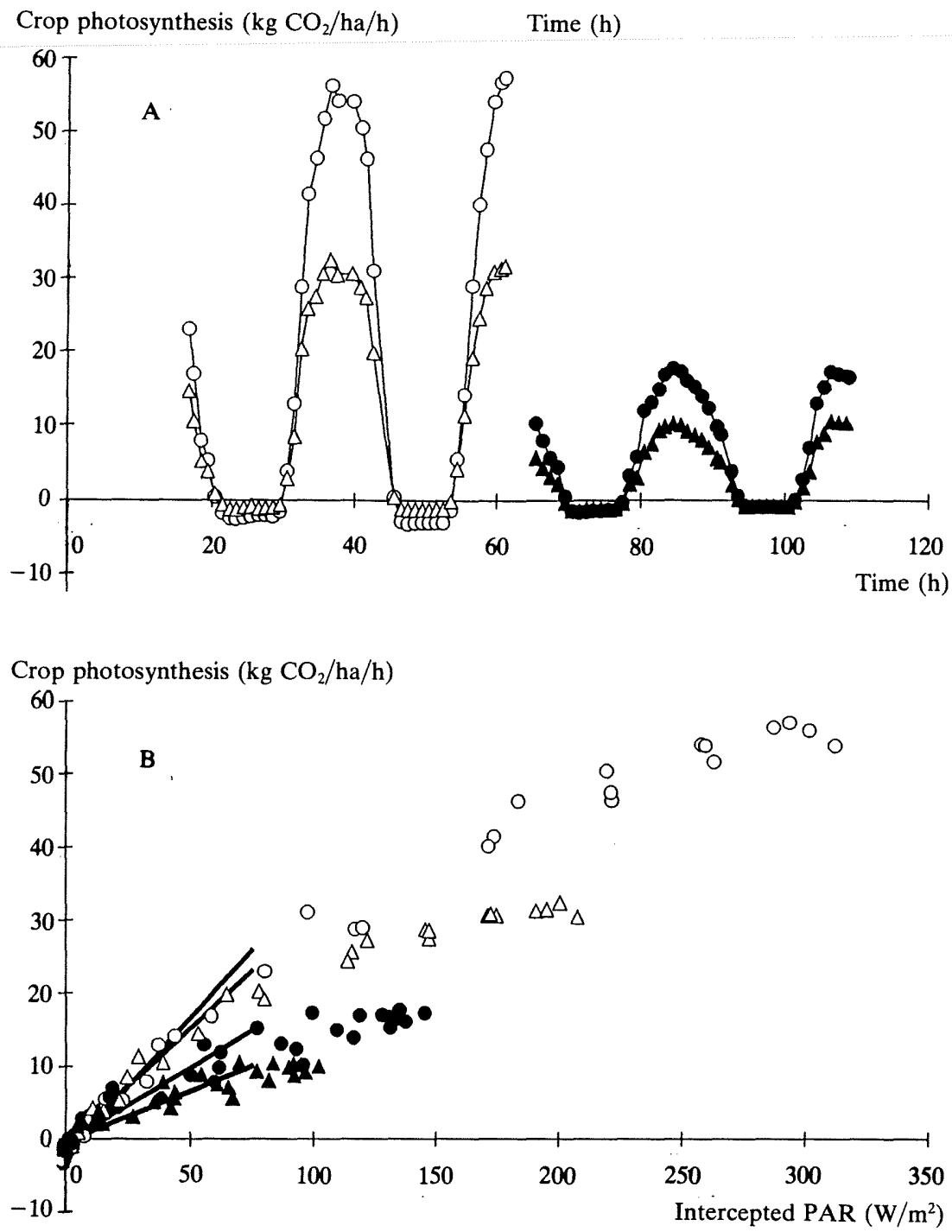

Fig. 5. Measurements with crop enclosures, cv. Darwina, 1-5 July 1991. A: Diurnal courses of crop photosynthetic rate $\left(\mathrm{kg} \mathrm{CO}_{2} \mathrm{ha}^{-1}\right.$ ground area $\left.\mathrm{h}^{-1}\right)$, for various treatments; B: Same data on photosynthetic rate as in $\mathrm{A}$, but relative to concurrent rates of interception of photosynthetically active radiation ( $\mathrm{W} \mathrm{m}^{-2}$ ground area). The graph also shows the linear regression lines for photosynthetic rate as a function of intercepted radiation under non-light saturating conditions (below $75 \mathrm{~W} \mathrm{~m}^{-2}$ ), the slopes of which indicate crop photosynthetic light use efficiency (PLUE, see Table 4). - - - Non-compacted, fumigated; $\longrightarrow$ compacted, fumigated; $-\Delta-$ non-compacted, not fumigated; $-\boldsymbol{\Delta}-$ compacted, not fumigated.

\section{Root length dynamics}

In both years root length increased mainly in the number of days between planting and early July (Fig. 6). On non-compacted soil with few nematodes, all cultivars reached root lengths between 9 and $16 \mathrm{~km} \mathrm{~m}^{-2}$. Root length was largest in cv. Elles, with only small differences among the other cultivars. In 1991, high nematode density and soil compaction reduced root length strongly, especially in $\mathrm{cv}$. Elles. In 1992, root length was greater than 
Table 3. Crop Photosynthetic Light Use Efficiency (PLUE; $\mathrm{gCO}_{2} \mathrm{MJ}^{-1}$ ) and leaf photosynthetic rate at light saturation $\left(P M A X ; m g \mathrm{CO}_{2} \mathrm{~m}^{-2} \mathrm{~s}^{-1}\right)$. SED = standard error of difference

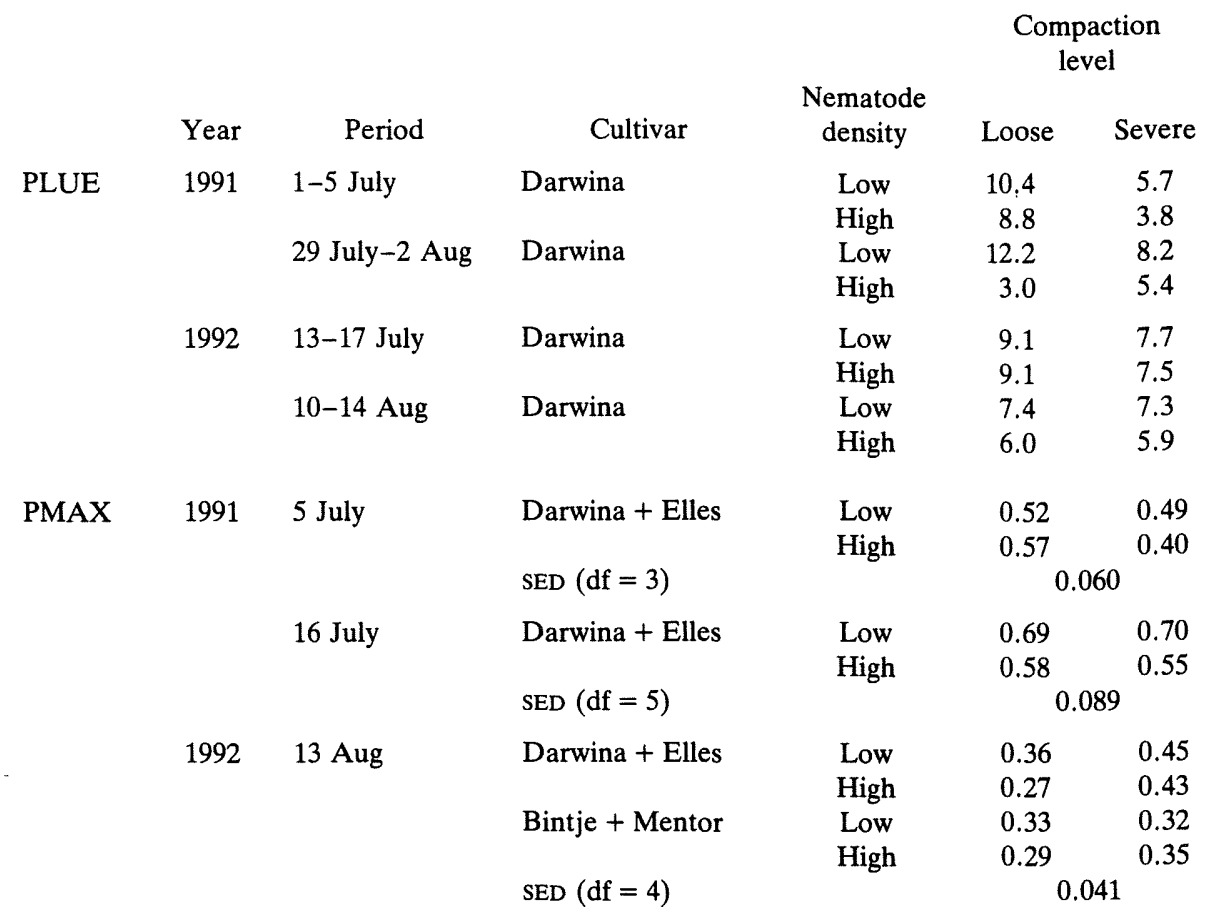

in 1991 but the treatments had no statistically significant effect (Fig. 6). The large root length reduction of cv. Elles in 1991 was more than offset by its high inherent root length, so for each treatment and harvest time cv. Elles still had a larger root system than cv. Darwina.

\section{Spatial distribution of roots}

Root length data for the various sampling positions were used to calculate the relative vertical and horizontal extension of roots. Vertical extension was quantified as the root length density below $0.2 \mathrm{~m}$ depth divided by the density above $0.2 \mathrm{~m}$. Horizontal extension was quantified similarly as the ratio of root length densities in between planting positions and directly below plants. Even at the latest harvest, a fully homogeneous root distribution, with both ratios equal to one, was not found (Table 4). High nematode density reduced root spatial extension only in 1991, with average reductions of $30 \%$ and $13 \%$ for vertical and horizontal extension, respectively (Table 4). Severe soil compaction affected vertical and horizontal extension in 1991 by $32 \%$ and 55\%, respectively, and in 1992 by $10 \%$ and $43 \%$, respectively (Table 4). There were no statistically significant interactions between high nematode density and soil compaction for horizontal or vertical root extension. The spatial distribution of roots did not differ significantly among the cultivars.

\section{Specific root length and root-shoot ratio}

Soil compaction reduced root weight to a similar extent as root length. High nematode density primarily affected root weight and thus increased the specific root length (SRL: $m$ root $\mathrm{g}^{-1}$ root weight), especially in 1991 (Table 5). The cultivars differed strongly for SRL, with cv. Elles having the lowest SRL at both nematode densities in both years. 
Darwina, 1991 :

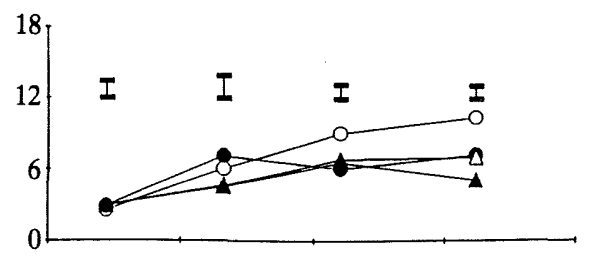

Darwina, 1992

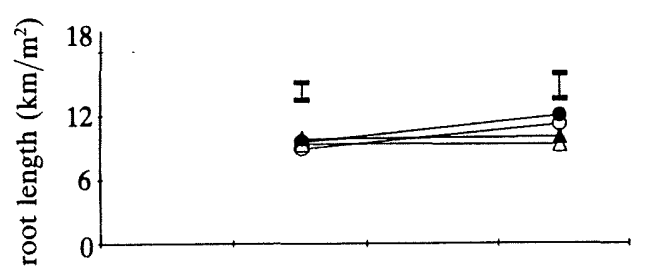

Bintje, 1992

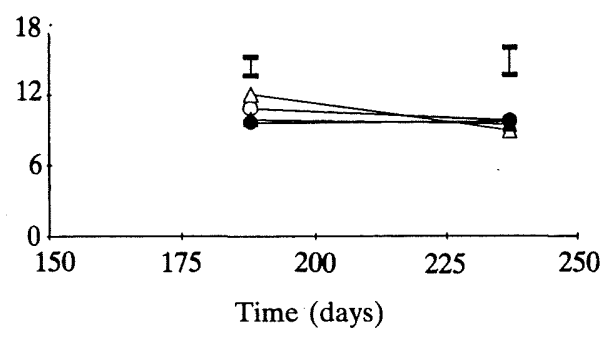

Elles, 1991

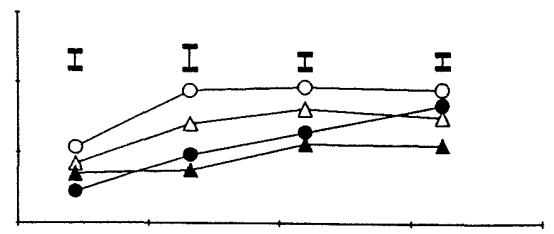

Elles, 1992

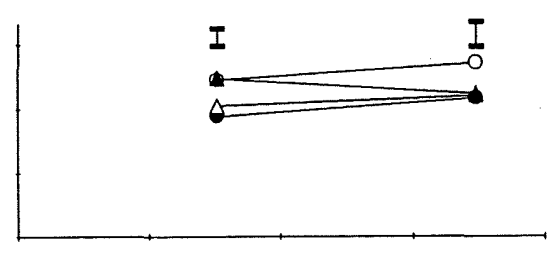

Mentor, 1992

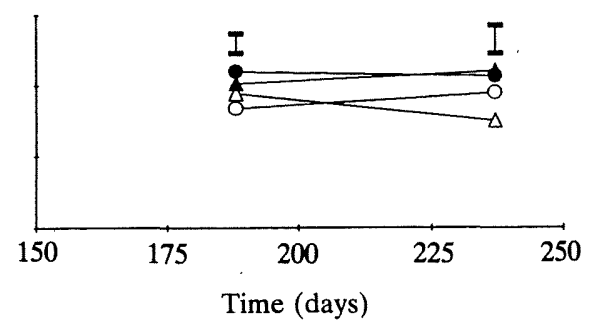

Fig. 6. Time courses of total root length $\left(\mathrm{km} \mathrm{m}^{-2}\right)$, for various treatments. Vertical bars above harvest data indicate standard eتrrors of difference $(1991: \mathrm{df}=12 ; 1992: \mathrm{df}=36)$. - - - Non-compacted, fumigated; $\longrightarrow$ - compacted, fumigated; $-\Delta-$ non-compacted, not fumigated; $-\boldsymbol{\Delta}-$ compacted, not fumigated.

Root-shoot ratios (Table 6) decreased strongly during the season, but treatment effects were consistent, so only data for the second harvest are given. Soil compaction increased root-shoot ratio in both years (Table 6), but high nematode density did not cause any statistically significant effects. Cultivar differences in root-shoot ratio resembled those in SRL, but in the opposite direction: cv. Elles had the highest root-shoot ratio for most treatments in both years.

\section{Root senescence}

In both years root senescence rate was about $1 \%$ day $^{-1}$ for all cultivars growing under optimal conditions, i.e. fumigated, non-compacted soil. Statistically significant acceleration of root senescence due to nematodes or compaction was only observed in 1991. In that year either high nematode density or soil compaction or both accelerated root senescence of cv. Darwina, up to $4-6 \%$ day $^{-1}$, but only the combination of both stress-factors caused a similar acceleration in cv. Elles. 
Table 4. Spatial distribution of roots at harvest 4 (19 August 1991; 24 August 1992). Vertical extension is calculated as the ratio of root length density ( $R L D, m$ root $\mathrm{cm}^{-3}$ soil) at depth $0.2-0.4 \mathrm{~m}$ relative to $R L D$ at depth $0.0-0.2 \mathrm{~m}$. Horizontal extension is calculated as the ratio of $R L D$ in soil columns $(0.0-0.4 \mathrm{~m})$ between plants relative to $R L D$ in soil columns below plants. Differences between cultivars were not significant, so only average data for all cultivars are given. $S E D=$ standard error of difference

\begin{tabular}{|c|c|c|c|c|c|c|c|}
\hline & \multirow[b]{2}{*}{ Year } & & \multicolumn{2}{|c|}{ Nematode density } & \multicolumn{3}{|c|}{ Compaction level } \\
\hline & & & Low & High & Loose & Light & Severe \\
\hline \multirow[t]{2}{*}{$\begin{array}{l}\text { Vertical } \\
\text { extension }\end{array}$} & 1991 & $\begin{array}{l}\text { mean } \\
\operatorname{SED}(\mathrm{df}=18)\end{array}$ & 0.61 & 0.43 & 0.63 & $\begin{array}{c}0.50 \\
0.081\end{array}$ & 0.43 \\
\hline & 1992 & $\begin{array}{l}\text { mean } \\
\operatorname{SED}(\mathrm{df}=36)\end{array}$ & 0.51 & 0.68 & 0.63 & 0.080 & 0.56 \\
\hline \multirow[t]{2}{*}{$\begin{array}{l}\text { Horizontal } \\
\text { extension }\end{array}$} & 1991 & $\begin{array}{l}\text { mean } \\
\operatorname{SED}(d f=18)\end{array}$ & 0.70 & 0.61 & 0.96 & $\begin{array}{l}0.57 \\
0.146\end{array}$ & 0.44 \\
\hline & 1992 & $\begin{array}{l}\text { mean } \\
\operatorname{SED}(\mathrm{df}=36)\end{array}$ & 0.73 & 0.71 & 0.92 & 0.092 & 0.52 \\
\hline
\end{tabular}

Table 5. Specific root length ( $\mathrm{m} \mathrm{g}^{-1}$ root fresh weight), average of four harvest dates. Effects of soil compaction were not statistically significant and are not shown in the Table. SED = standard error of difference (value in parentheses is for the comparison within the same level of nematode density)

\begin{tabular}{llccc} 
& & \multicolumn{3}{c}{ Nematode density } \\
Year & \multicolumn{1}{c}{ Cultivar } & Low & High \\
1991 & Darwina & 79 & 113 \\
& Elles & 56 & 62 \\
& SED $(\mathrm{df}=12)$ & & $13.2(9.3)$ & \\
1992 & Darwina & 73 & & 54 \\
& Elles & 32 & & 41 \\
& Bintje & 65 & & 98 \\
& Mentor & 59 & & 57 \\
& SED $(\mathrm{df}=36)$ & & $17.3(16.6)$
\end{tabular}

Table 6. Root-shoot ratio at the second harvest (2 July 1991; 6 July 1992), calculated as the dry weight ratio of the roots and the sum total of stems, leaves and tubers. Root dry weight is estimated as 0.08 times root fresh weight. SED $=$ standard error of difference (value in parentheses is for the comparison within the same level of soil compaction)

\begin{tabular}{cc} 
Compaction level & \\
Light & Severe \\
0.040 & 0.049 \\
0.071 & 0.111 \\
$0.0241(0.0187)$ & \\
& 0.079 \\
& 0.106 \\
& 0.066 \\
& 0.101 \\
\hline $0.0208(0.0205)$ &
\end{tabular}




\section{Nutrient concentrations}

At all harvest dates, concentrations of nitrogen, phosphorus and potassium were measured in leaves, stems and tubers. The concentrations decreased during the growing season, especially in leaves and stems. An exception to this pattern was found in plants on compacted soil in 1991, where the initial reduction in leaf and stem $\mathrm{N}$-concentration was reversed at the later harvests (Fig. 7A). In most other cases treatment effects on nutrient concentrations remained consistent during the season, so only seasonal averages were subjected to analysis of variance (Table 7).

Both high nematode density and soil compaction significantly decreased all nutrient concentrations in 1991. In 1992 the effects were much smaller, albeit still statistically significant except for $\mathrm{N}$ and $\mathrm{K}$ in stems and leaves (Fig. 7, Table 7). Percentage reductions in nutrient concentration were lowest for nitrogen and highest for potassium. However, leaf nitrate-N, only measured in 1991, responded most strongly to the treatments. The reductions were largest in stem tissue and lowest in the tubers.

Compared to the effects of nematodes and soil compaction, differences among cultivars in nutrient concentration were small (Table 7). Moreover, only in three cases (all in 1992: leaf $\mathrm{P}$ and $\mathrm{K}$, stem $\mathrm{P}$ ) significant interactions of cultivar with soil treatment were found. These interactions explained less than $3.2 \%$ of measured variation, so the nutrient concentrations of the cultivars differed as little in their response to treatments as in their average values. Table 7 only shows the average values.

Table 7. Nutrient concentrations ( $g \mathrm{~kg}^{-1}$ dry matter), for non-compacted, fumigated soil (Control), non-fumigated soil (Nematodes), severely compacted soil (Compaction) and nonfumigated, severely compacted soil (Nemotodes + Compaction). Data are averages for all harvest dates. For each of the 19 combinations of year (1991/1992), organ (leaves, stems, tubers) and nutrient (total nitrogen, nitrogen in nitrate, phosphorus, potassium) a separate analysis of variance was carried out and standard errors of difference (SED) calculated

Year

1991 Control

Nematodes

Compaction

Nematodes + Compaction

SED $(\mathrm{df}=6)$

Darwina

Elles

$\operatorname{SED}(d f=6)$

1992 Control

Nematodes

Compaction

Nematodes + Compaction

$\operatorname{SED}(\mathrm{df}=12)$

Darwina

Elles

Bintje

Mentor

$\operatorname{SED}(\mathrm{df}=12)$
Leaves

Stems

$\begin{array}{ccccc}\mathrm{N} & \mathrm{NO}_{3}^{-} & \mathrm{P} & \mathrm{K} & \mathrm{N} \\ 52.2 & 4.4 & 4.2 & 50.3 & 29.0 \\ 46.7 & 2.7 & 3.7 & 40.2 & 22.1 \\ 47.1 & 1.7 & 3.4 & 40.3 & 21.6 \\ 41.4 & 1.5 & 3.0 & 31.0 & 18.9 \\ 1.53 & 0.43 & 0.22 & 2.22 & 1.60 \\ 45.6 & 2.3 & 3.5 & 41.0 & 22.6 \\ 47.4 & 2.5 & 3.7 & 38.9 & 21.9 \\ 0.47 & 0.10 & 0.05 & 0.99 & 0.79\end{array}$

$51.6-3.3$

$50.0-$

$51.0-$

48

$0.26-$

$50.7-3.0$

53.3 - 3.3

$48.6-2.9$

$48.5-$

0.90

$\begin{array}{lcclc}\mathrm{P} & \mathrm{K} & \mathrm{N} & \mathrm{P} & \mathrm{K} \\ 3.6 & 66.5 & 15.2 & 2.5 & 21.6 \\ 2.5 & 42.2 & 12.3 & 1.9 & 16.8 \\ 2.4 & 40.3 & 14.5 & 1.9 & 18.8 \\ 2.2 & 28.4 & 13.4 & 2.1 & 18.0 \\ 0.16 & 2.53 & 1.24 & 0.06 & 0.75 \\ 2.5 & 43.2 & 14.0 & 2.1 & 19.0 \\ 2.8 & 44.2 & 13.1 & 2.2 & 18.6 \\ 0.08 & 1.68 & 0.71 & 0.06 & 0.72 \\ & & & & \\ 2.8 & 58.9 & 15.8 & 2.3 & 21.9 \\ 2.1 & 52.1 & 15.5 & 1.9 & 20.8 \\ 2.2 & 56.2 & 16.4 & 1.9 & 22.3 \\ 2.0 & 51.2 & 17.0 & 1.8 & 22.5 \\ 0.11 & 3.15 & 0.35 & 0.07 & 0.63 \\ 2.3 & 54.3 & 15.3 & 1.9 & 21.9 \\ 2.8 & 55.9 & 14.2 & 2.1 & 21.8 \\ 2.3 & 53.8 & 18.6 & 2.1 & 22.2 \\ 1.8 & 54.5 & 16.6 & 1.8 & 21.5 \\ 0.06 & 1.34 & 0.42 & 0.07 & 0.36\end{array}$



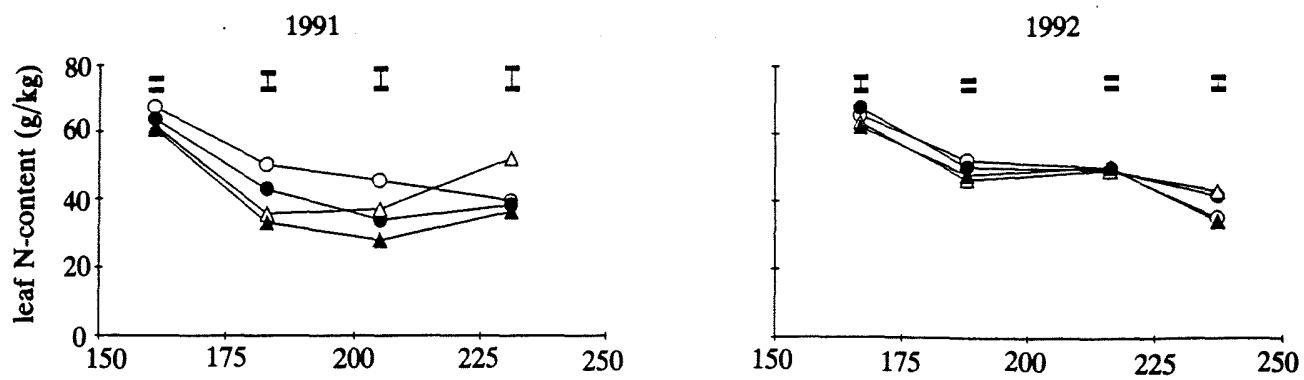

Fig. 7. Time courses of leaf nitrogen concentration ( $\mathrm{g} \mathrm{N} \mathrm{kg}^{-1}$ dry matter) in cultivar Darwina. Treatments and symbols as in Fig. 6. Vertical bars above harvest data indicate standard errors of difference (1991: $\mathrm{df}=6 ; 1992: \mathrm{df}=12) .-\mathrm{O}$ Non-compacted, fumigated; $\longrightarrow$ compacted, fumigated; $-\Delta-$ noncompacted, not fumigated; $-\boldsymbol{\Delta}-$ compacted, not fumigated.
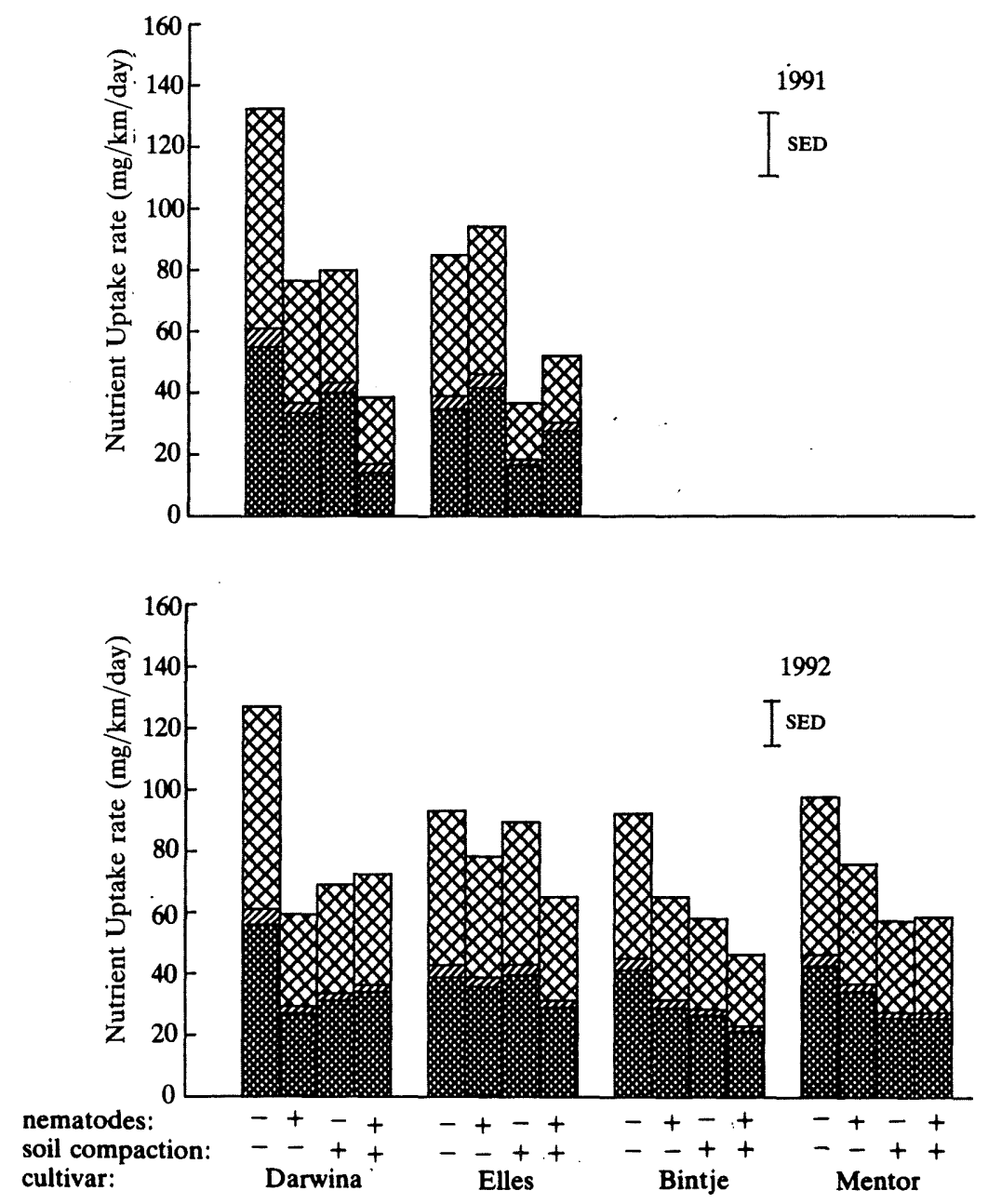

Fig. 8. Average inflow rates (mg nutrient $\mathrm{km}^{-1}$ root day ${ }^{-1}$ ), between first and fourth harvest, of nitrogen$\mathrm{N}$. $+:$ high, not fumigated) and two levels of soil compaction (-: non-compacted; $+:$ severely compacted). Error bars indicate standard errors of difference for total nutrient inflow rate $(N+P+K)$. 


\section{Nutrient inflow rates}

The data of nutrient concentrations were combined with data of total biomass and root length, to calculate nutrient inflow rates, i.e. rates of nutrient uptake per unit root length per day (Fig. 8). High nematode density and soil compaction reduced inflow rates for nitrogen, phosphorus and potassium. No consistent differences between years or cultivars were found, except for a higher nutrient inflow rate in cv. Darwina in the absence of stress factors.

\section{Discussion}

\section{Effectivity of nematicide and compaction treatments}

Nematicide application reduced nematode density by $91 \%$ in 1991 , and by $85 \%$ in 1992 . It is not clear what caused the greater nematicide effectivity, at lower dose rate, in 1991. The nematicide applied may have killed other soil organisms interacting with the crops, but since cyst nematode density was high in both years, we assume that the established differences in nematode density dominated the effects of fumigation on crop growth.

In 1991, the compaction procedure was more effective in increasing soil penetration resistance at depths greater than $15 \mathrm{~cm}$, than it was in 1992 (Fig. 1), possibly because of the low soil water content in the latter year. Compaction probably did not affect the nematodes themselves, because unlike migratory plant-parasitic nematodes, which lack a protective cyst, cyst nematodes are not sensitive to mechanical damage (Boag, 1988).

\section{Interaction of nematodes and soil type}

Both high nematode density and soil compaction reduced final tuber yields (Table 1). The effects were mostly additive with but one exception: cv. Elles suffered yield loss due to nematodes only on compacted soil in 1991. Our experiments therefore did not confirm the results of Whitehead \& Nichols (1992), who found greatest losses on loose soil. Variation among soil types in yield loss by similar densities of nematodes (Trudgill, 1986; Evans \& Haydock, 1990) therefore is probably caused by differences in soil characteristics other than penetration resistance to root growth.

\section{Differences between nematodes and soil compaction}

The effects of soil compaction were similar for all cultivars in our experiments, so no cultivar with tolerance of compaction was identified. The cultivars did respond differently to nematodes, with cv. Elles the most tolerant. Nematodes and compaction also differed in that only the nematode effect varied strongly between the two experimental years. We conclude that nematodes and compaction affect potato growth by different damage mechanisms, which may explain their largely additive effect on yield.

In the absence of interactions, the main effects are summarised in Table 8 for cvs Darwina and Elles, grown in both experiments. Yield loss due to nematodes averaged $26 \%$ for these cultivars over both years. This was mainly accounted for by reduction in cumulative light interception (PARCUM) with less reduction of the light use efficiency (LUE) (Table 8). Compaction caused similar losses as nematodes ( $27 \%$ on average) but mainly affected LUE. Part of the reductions of PARCUM were caused by reduced LUE-values, because a lower LUE will lead to a reduced crop growth rate resulting in less light intercepting leaf area. However, both nematodes and compaction also reduced PARCUM more directly than via LUE, namely by reducing SLA and accelerating leaf senescence (Table 8). Compaction further reduced PARCUM by decreasing the fraction of biomass allocated to leaves early 
Table 8. Average effects (\% change compared with plants from fumigated, non-compacted plots) of high nematode density and severe soil compaction on crop characteristics of cus Darwina and Elles in both experiments

\begin{tabular}{lcrrrc} 
& \multicolumn{5}{c}{ Effect of nematodes } \\
Crop characteristic & Darwina & Elles & 1991 & 1992 & $\begin{array}{c}\text { Effect of } \\
\text { compaction }\end{array}$ \\
Yield $^{1}$ & -42 & -9 & -40 & -12 & -27 \\
PARCUM $^{1}$ & -39 & -12 & -41 & -10 & -15 \\
LUE $^{1}$ & -12 & -13 & -20 & -5 & -20 \\
SLA & -7 & -6 & -9 & -3 & -11 \\
Leaf senescence $^{2}$ & +107 & +34 & +139 & +4 & +7 \\
PLUE $^{3}$ & -25 & & -40 & -9 & -23 \\
PMAX $^{3}$ & & & -13 & -15 & +7
\end{tabular}

${ }^{1}$ Data derived from Table 1

${ }^{2}$ Data derived from Table 2

${ }^{3}$ Data derived from Table 3.

in the growing season (Fig. 4). Nematodes did not affect partitioning between leaves, stem and tubers, and any change of root-shoot partitioning was probably small (Table 6).

This analysis of the component factors determining PARCUM reveals further differences between the damage mechanisms of nematodes and soil compaction. Nematodes mainly reduce PARCUM by accelerating leaf senescence, while compaction mainly reduces PARCUM by reducing LUE and SLA and initially also by decreasing partitioning to leaves (Table 8; Fig. 4). Therefore compaction mainly delays crop closure early in the growing season, whereas nematodes primarily accelerate foliage death during later growth stages (compare Fig. 3).

The measurements of crop and leaf photosynthesis (PLUE, PMAX) tend to confirm the observed reductions of LUE (Table 8), except for the increase in PMAX by compaction at the end of the growing season. The late-season stimulative effect of compaction, which was also observed for ground cover (Fig. 3) may be explained by slower depletion of soil nutrients and water by the slow growing plants on compacted soil.

\section{Differences among cultivars for tolerance to nematodes}

The same analysis of PARCUM and LUE can be applied to explain the relatively strong tolerance of cv. Elles to nematodes. Cv. Elles suffers equal reductions of LUE as the other cultivars and its tolerance is therefore based on a smaller reduction of PARCUM (Table 8). Surprisingly, nematodes affected SLA and leaf senescence of cv. Elles to the same extent as in the other cultivars, while partitioning was unaffected in all cultivars, as indicated above. We conclude that the tolerance of $\mathrm{cv}$. Elles is not caused by a better response to nematode infestation, but rather by a more favourable growth habit, in which much leaf area is produced because of a prolonged partitioning of biomass to leaves (Fig. 4) and a high SLA. This confirms the findings of Trudgill (1986), who found relatively low nematodeinduced yield loss in cultivars with large tops. Since prolonged partitioning to leaves is a common characteristic of late maturing potato cultivars, we expect yield loss to be negatively correlated with cultivar lateness.

\section{Root growth}

Root length growth can be considered as the product of three factors: overall crop growth rate, the fraction of growth that appears as root biomass, and the specific root length. Net 
root length increase is the difference of this product and root senescence rate. Both net root length increase and its four constituents have been quantified so the main determinants of treatment effects can now be identified.

Soil compaction reduced net root length growth (Fig. 6) less than overall crop growth (Fig. 2, Table 1), although root senescence was accelerated and specific root length unchanged. Compaction thus must have stimulated allocation of biomass to roots, as also indicated by increased root-shoot ratios in both years (Table 6).

Nematodes also accelerated root senescence in 1991 but seemed to increase specific root length in both years (Table 5). Nematodes may have increased root branching near infected root tips, thereby increasing the frequency of thin roots and increasing average specific root length, but we did not collect morphological data to test this assumption. Although rootshoot ratios were not statistically significantly increased at high nematode density (Table 6 ), nematodes may have stimulated allocation of biomass to roots if an effect on root-shoot ratio was masked by increased root senescence.

Cv. Elles differed greatly from the other cultivars in root characteristics. Although the specific root length of cv. Elles was lowest (Table 5), its total root length was highest (Fig. 6) because of the large fraction of biomass allocated to roots (Table 6). Nematodes and soil compaction increased root senescence in cv. Elles less than in cv. Darwina, especially in 1991. Possibly, the relatively thick roots of $\mathrm{cv}$. Elles afforded some protection against damage.

In summary, whenever root length was reduced, the main cause was accelerated root senescence rather than impaired root growth. Plants tended to minimise the reduction of root length density by increasing allocation to roots and, with nematodes, by increasing the specific root length.

\section{Nutrient concentrations}

Nutrient concentrations were positively correlated with total root length. The large reductions of root length in 1991 (Fig. 6) coincided with large reductions of nutrient concentrations (Table 7), while both variables were relatively unaffected by treatments in 1992. Both root length and leaf concentrations of nitrogen and phosphorus were significantly higher in cv. Elles than in the other cultivars. However, concentration-reducing treaments generally increased root-shoot ratios (Table 6), leaving less plant weight to be supplied with nutrients per unit root weight and length. We therefore conclude that the correlation between concentrations and root length has no causal basis, and variation in concentrations must therefore be explained by factors affecting uptake per unit root length (Fig. 8) rather than root system size.

High nematode density and soil compaction may have reduced the capacity for nutrient uptake by restricting vertical and horizontal extension of roots (Table 4), leading to insufficient soil colonisation and exhaustion of nutrients within reach. However, a direct effect of nematode infection on uptake capacity of roots cannot be excluded.

\section{Mechanisms of yield loss}

Both reduction of light interception and reduction of light use efficiency have been shown to be involved in the response of potato cultivars to nematodes and soil compaction. However, these reductions are but the end-result of primary responses originating in the root system. The reported data on root length dynamics and nutrient uptake allow us to elucidate the link between root and shoot responses. In 1992, high nematode density and soil compaction had little effect on nutrient concentrations (Table 7), nor did they affect leaf senescence (Table 2). However, high nematode density did decrease yields in 1992, by 
$23 \%$ on average for the intolerant cvs Darwina, Bintje and Mentor, while compaction reduced yields by $20 \%$ (Table 1 ). We conclude that nutrient deficiency was not the likely cause of damage in 1992. Nematodes and compaction probably did not induce water stress either, since the plants were repeatedly irrigated, and soil water contents remained equally high for all treatments. Passioura (1988) and Masle (1990) have shown for drought and soil compaction, respectively, that soil-related stress factors may trigger hormonal root signals which impair shoot functioning. The same mechanism has been proposed, on the basis of pot experiments, for potato cyst nematodes (Schans, 1991), following earlier findings that abscisic acid concentrations were increased after potato cyst nematode infection (Fatemy, Trinder, Wingfield \& Evans, 1985). Possibly, the present results for 1992, i.e. nematode damage without nutrient deficiency, may be explained in a similar manner.

In 1991, yield losses were much higher than in 1992. Moreover, the losses were accompanied by strong reductions of nutrient concentrations. Nutrient deficiency may therefore have caused the extra high losses. Occurrence of nutrient deficiency in 1991 may also explain why only in that year leaf senescence rates were accelerated (Table 2). However, it seems probable that even in 1991 nutrient deficiency only occurred in the second half of the growing season, since differences between nutrient concentrations only became prominent from the time of the second harvest (Fig. 7A). Foliage development was by then already. strongly reduced by nematodes so root signalling rather than nutrient deficiency may have caused the initial delay of crop growth.

The results do not allow conclusions as to which of the nutrients became deficient, since concentrations of N, P and K were all reduced. Lorenz \& Tyler (1983; cited by Walworth \& Muniz, 1993) reported that mid-season concentrations in potato leaf blades of $5 \% \mathrm{~N}$, $0.4 \% \mathrm{P}$ and $3.5 \% \mathrm{~K}$ are sufficient for maximum growth. If these data apply to our cultivars and conditions as well, only phosphorus levels may have become deficient (Table 7). Nutrient concentrations were reduced to a similar extent in all cultivars, including the tolerant $\mathrm{cv}$. Elles, which suffered relatively little yield loss. However, the absolute uptake rate of nutrients $\left(\mathrm{g} \mathrm{m}^{-2}\right.$ soil day $\left.{ }^{-1}\right)$ was always highest in cv. Elles, and dry matter increase was least impaired. Although this does not prove a causal relationship, it does suggest that uptake rates are better suited than concentrations as indicators of nutrient deficiency. The high level of tolerance of cv. Elles may thus be explained by its producing the largest root system and thereby maintaining the highest nutrient uptake rates. A positive correlation of root length of potato cultivars with tolerance of cyst nematodes has earlier been indicated by Evans \& Haydock (1990).

It is not completely clear why high nematode density led to strong root length reduction and nutrient deficiency only in 1991, given that the initial density of nematodes was higher in the following year. The higher soil temperatures in 1992 may have provided better conditions for root growth (Fig. 6), but that does not explain the smaller effect of nematodes on root length. Possibly, movement and penetration efficiency of the nematodes was hampered by the somewhat drier conditions in 1992 , even though the irrigation was sufficient to prevent any visible drought symptoms on the plants themselves and control yields were similar in both years.

The results of this paper do not explain the common observation that nematode damage varies with soil type (Trudgill, 1986). Nematodes and compaction mostly showed additive effects, both at the level of overall crop growth and at the level of the underlying processes of root length dynamics and nutrient uptake. Variation in soil density or penetration resistance thus does not seem to affect the plant-pest relationship.

The field experiments reported here lead to the following general scheme of nematoderelated damage to crops. The primary response to nematodes, possibly initiated by hormonal root signals, involves impairment of photosynthesis, a decrease in specific leaf area, and 
possibly also a decreased allocation of biomass to tubers and shoot in favour of root growth. A secondary response may follow if nematode infection is so severe that root lengths are strongly decreased, leading to chronic nutrient deficiency (Trudgill, 1980) in the second half of the growing season, and, finally, acceleration of crop senescence.

In this paper we have analysed nematode-related damage mechanisms in some detail, and identified various ways in which crop growth was affected. This will provide data for the further development of a computer model which simulates dynamically the interaction between the growing crop and the nematode population in soil and roots (Van Oijen, De Ruijter \& Van Haren, 1995). The model is intended to define the characteristics that make a cultivar tolerant.

\section{Acknowledgements}

We thank J Smit for allowing the use of his fields. $M$ van de Waart, $M$ Boerma and $R$ Velema helped in planning and preparation of the experiments. H Peeters, J Derksen, E M L Hendrikx, F H M Ammerlaan, J van Kleef and the chemical laboratory of AB-DLO are acknowledged for technical assistance. A J Haverkort and A $\mathrm{K}$ van der Werf commented on the manuscript.

\section{References}

Anon. 1992. 67th descriptive list of varieties of field crops. Maastricht: Leiter-Nypels. 337 pp.

Bengough A G. 1991. The penetrometer in relation to mechanical resistance to root growth. In Soil analysis: Physical methods, pp. 421-445. Eds K A Smith and C E Mullins. New York: Marcel Dekker.

Boag B. 1988. Influence of ploughing, rotary cultivation and soil compaction on migratory plantparasitic nematodes. In Proceedings of the 11th Conference of the International Soil Tillage Research Organization, pp. 209-214.

Boone F R, Bouma J, De Smet L A H. 1978. A case study on the effect of soil compaction on potato growth in a loamy sand soil. 1. Physical measurements and rooting patterns. Netherlands Journal of Agricultural Science 26:405-420.

Dale M F B, Phillips M S, Ayres R M, Hancock M, Holliday J M, Mackay G R, Tones S J. 1988. The assessment of the tolerance of partially resistant potato clones to damage by the potato cyst nematode Globodera pallida at different sites and in different years. Annals of Applied Biology 113:79-88.

Evans K, Haydock P P J. 1990. A review of tolerance by potato plants of cyst nematode attack, with consideration of what factors may confer tolerance and methods of assaying and improving it in crops. Annals of Applied Biology 117:703-740.

Fatemy F, Trinder P K E, Wingfield J N, Evans K. 1985. Effects of Globodera rostochiensis, water stress and exogenous abscisic acid on stomatal function and water use of Cara and Pentland Dell potato plants. Revue de Nématologie 8:249-255.

Glinski J, Lipiec J. 1990. Soil physical conditions and plant roots. Boca Raton: CRC Press. $250 \mathrm{pp.}$

Hancock M, Holliday J M. 1992. White potato cyst nematode: the relationship between population size and tuber yield in an organic soil. Aspects of Applied Biology 33, Production and protection of potatoes, pp. 107-111.

Haverkort A J, Boerma M, Velema R, Van de Waart M. 1992. The influence of drought and cyst nematodes on potato growth. 4. Effects on crop growth under field conditions of four cultivars differing in tolerance. Netherlands Journal of Plant Pathology 98:179-191.

Haverkort A J, Uenk D, Veroude H, Van de Waart M. 1991. Relationships between ground cover, intercepted solar radiation, leaf area index and infrared reflectance of potato crops. Potato Research 34:113-121. 
Lorenz O A, Tyler K B. 1983. Plant tissue analysis of vegetable crops. In Soil and Plant Tissue Testing in California. University of California Bulletin No. 1879.

Louwerse W, Eikhoudt J W. 1975. A mobile laboratory for measuring photosynthesis, respiration and transpiration of field crops. Photosynthetica 9:31-34.

Masle J. 1990. Growth and stomatal behaviour: response to soil resistance to root penetration. In Importance of root to shoot communication in the responses to environmental stress, pp. 95-113. Eds W J Davies and B Jeffcoat. British Society for Plant Growth Regulation, Monograph 21.

Monteith J L. 1977. Climate and the efficiency of crop production in Britain. Philosophical Transactions of the Royal Society of London, Series B 281:277-294.

Passioura J B. 1988. Root signals control leaf expansion in wheat seedlings growing in drying soil. Australian Journal of Plant Physiology 15:687-693.

Schans J. 1991. Reduction of leaf photosynthesis and transpiration rates of potato plants by secondstage juveniles of Globodera pallida. Plant, Cell and Environment 14:707-712.

Schans J, Arntzen F K. 1991. Photosynthesis, transpiration and plant growth characters of different potato cultivars at various densities of Globodera pallida. Netherlands Journal of Plant Pathology 97:297-310.

Smucker A J M, McBurney S L, Srivastava A K. 1982. Quantitative separation of roots from compacted soil profiles by the hydropneumatic elutriation system. Agronomy Journal 74:500-503.

Tennant D. 1975. A test of a modified line intersect method of estimating root length. Journal of Ecology 63:995-1001.

Trudgill D L. 1980. Effect of Globodera rostochiensis and fertilisers on the mineral nutrient content and yield of potato plants. Nematologica 26:243-254.

Trudgill D L. 1986. Yield losses caused by potato cyst nematodes: a review of the current position in Britain and prospects for improvements. Annals of Applied Biology 108:181-198.

Trudgill D L, Cotes L M. 1983a. Differences in the tolerance of potato cultivars to potato cyst nematodes (Globodera rostochiensis and $G$. pallida) in field trials with and without nematicides. Annals of Applied Biology 102:373-384.

Trudgill D L, Cotes L M. 1983b. Tolerance of potato to potato cyst nematodes Globodera rostochiensis and Globodera pallida in relation to the growth and efficiency of the root system. Annals of Applied Biology 102:385-397.

Trudgill D L, Evans K, Parrott D M. 1975. Effects of potato cyst-nematodes on potato plants. II. Effects on haulm size, concentration of nutrients in haulm tissue and tuber yield of a nematode resistant and a nematode susceptible potato variety. Nematologica 21:183-191.

Trudgill D L, Marshall B, Phillips M S. 1990. A field study of the relationship between pre-planting density of Globodera pallida and the growth and yield of two potato cultivars of differing tolerance. Annals of Applied Biology 117:107-118.

Upchurch D R, Ritchie J T. 1983. Root observations using a video recording system in mini-rhizotrons. Agronomy Journal 75:1009-1015.

Van Haren R J F. 1995. Application of dynamic energy budgets to xenobiotic kinetics in Mytilus edulis and population dynamics of Globodera pallida. Ph.D. Thesis, Wageningen Agricultural University. 158 pp.

Van Oijen M, De Ruijter F J, Van Haren R J F. 1995. Modelling the interaction between potato crops and cyst nematodes. In Potato ecology and modelling of crops under conditions limiting growth, pp. 185-196. Eds A J Haverkort and D K L MacKerron. Dordrecht, The Netherlands: Kluwer Academic Publishers.

Walworth J L, Muniz J E. 1993. A compendium of tissue nutrient concentrations for field-grown potatoes. American Potato Journal 70:579-597.

Whitehead A G, Nichols A J F. 1992. The effects of deep cultivation and oxamyl on control of potato cyst-nematode, Globodera rostochiensis. Annals of Applied Biology 120:65-72.

(Received 4 January 1995) 